\title{
Intra-specific diversity and host specificity within Pasteurella haemolytica based on variation of capsular polysaccharide, lipopolysaccharide and outer-membrane proteins
}

\author{
R. L. Davies' and W. Donachie ${ }^{2}$ \\ Author for correspondence: R. L. Davies. Tel: +441413398855 ext. 6685. Fax: +441413304600. \\ e-mail: gbma23@udcf.gla.ac.uk
}

1 Division of Infection and Immunity, IBLS, Joseph Black Building, University of Glasgow, Glasgow G12 8QQ, UK

2 Moredun Research Institute, 408 Gilmerton Road, Edinburgh EH17 7JH, UK

\begin{abstract}
Intra-specific diversity within Pasteurella haemolytica was assessed by analysing variation in the capsular polysaccharide (serotypes), lipopolysaccharide (LPS) and outer-membrane proteins (OMPs) of 184 isolates recovered from cattle and sheep. Four of 12 serotypes comprised $83 \%$ of the total number of isolates, including $A 1$ and $A 2$ as the most frequently recovered serotypes from cattle and sheep, respectively. Nine distinct LPS profiles were identified. Four different core-oligosaccharide patterns were present, each of which occurred alone as rough LPS and also in association with a single 0 antigen profile as smooth LPS; the ninth LPS type was also smooth but had a different 0 -antigen profile. The capsular serotypes could be divided into four groups based on the dominant LPS profile within each serotype: (1) A1, A6, A9, A12 and A5; (2) A2, A8, A14 and A16; (3) A7 and A13; and (4) A11. Smooth LPS of type 1A, which was found only in the first group, was associated primarily with bovine disease isolates, whereas rough LPS of types 1B and 3B were associated primarily with the group 2 serotypes and ovine disease isolates. Similarly, the variation of OMP profiles generated three groups: (1) A1, A6, A9, $A 12, A 5$ and A8; (2) A2, A14 and A16; and (3) A7, A11 and A13. Isolates belonging to groups 2 and 3 exhibited greater diversity in their OMP profiles than those belonging to group 1. Although the majority of group 3 isolates possessed profiles unique to that group, a smaller number of A7 isolates possessed profiles with similarities to those of serotypes A1 or A2. OMP profiles clearly differentiated bovine from ovine isolates of the same serotypes. The association both of specific LPS and OMP profiles with bovine or ovine disease isolates suggested a correlation between specific cell-surface structures and host specificity. The combined analysis of capsular serotypes, LPS types and OMP profiles identified seven major groups within $P$. haemolytica which were responsible for $59 \%$ of the disease cases, suggesting a clonal structure for this species. Overall, comparison of the capsular serotypes, LPS types and OMP profiles proved extremely useful for assessing diversity within P. haemolytica.
\end{abstract}

Keywords: Pasteurella baemolytica, diversity, capsular polysaccharide, lipopolysaccharide, outer-membrane proteins 


\section{INTRODUCTION}

Pasteurella baemolytica is a Gram-negative bacterium responsible for economically important diseases of ruminants, including pneumonic pasteurellosis or shipping fever in cattle, and pneumonic pasteurellosis and septicaemia in sheep (Frank, 1989; Gilmour \& Gilmour, 1989). Studies aimed at furthering our understanding of the virulence and pathogenesis of $P$. baemolytica are hindered by insufficient knowledge about diversity within the species. In numerous comparative studies of $P$. baemolytica, single strains of different serotypes are assumed to be representative of those particular serotypes, whereas, in reality, this is probably not the case (Gilmour et al., 1986; Gentry et al., 1988; Abdullah et al., 1990; Gerbig et al., 1992; Lacroix et al., 1993). The situation is further confused by the fact that $P$. baemolytica is not a single species but is actually a complex of bacteria consisting of a number of different species (Mutters $e t$ al., 1989). Traditionally, P. baemolytica has been subdivided into two biotypes, $A$ and $T$, based on biochemical characteristics, and 17 serotypes, based on variation in capsular polysaccharides (Adlam, 1989; Younan \& Fodor, 1995). However, in addition to biochemical and serological differences, epidemiological and pathogenic differences also exist between the $\mathrm{A}$ and $\mathrm{T}$ biotypes (Gilmour \& Gilmour, 1989) and the $\mathrm{T}$ biotype is now considered a different species, namely Pasteurella trebalosi (Sneath \& Stevens, 1990). P. baemolytica comprises 13 capsular serotypes, namely A1, A2, A5-A9, A11-A14, A16 and A17, although isolates belonging to serotype A11 do not fit easily into biotype $A$ and Frederiksen (1973) proposed a third biotype to accommodate them. In addition to isolates which fall into one of the above serotypes, approximately $10 \%$ of disease isolates from cattle and sheep are untypable (Fraser et al., 1982; Quirie et al., 1986). Although some untypable isolates are closely related to those of biotype $A$, others represent different species (Mutters et al., 1986; Davies et al., 1996).

The different serotypes of $P$. baemolytica exhibit significant variation in their association with disease in cattle and sheep. Whereas A1 is the predominant serotype associated with bovine pneumonic pasteurellosis, other serotypes are recovered infrequently from diseased cattle, although serotype A2 is often associated with healthy animals (Frank, 1989). In contrast, A2 is the most commonly isolated serotype from cases of ovine pneumonic pasteurellosis, followed by serotypes A7 and A9. Low numbers of serotype $A 6$ isolates are recovered from cases of both bovine and ovine pneumonic pasteurellosis. The frequent recovery of serotype $\mathrm{A} 1$ and $\mathrm{A} 2$ isolates from natural cases of disease in cattle and sheep, respectively, and the less frequent isolation of other serotypes from natural cases of disease in both species, suggests important differences between the various serotypes which are reflected by differences in host specificity and virulence. However, very little is known about diversity within and relationships between the different $P$. baemolytica serotypes and, in particular, about variation of cell-surface components likely to be involved in virulence, including lipopolysaccharide (LPS) and outer-membrane proteins
(OMPs). In previous studies, Ali et al. (1992) and McCluskey et al. (1994) described variation in the LPS and OMP profiles of a small number of serotype A1 and A2 P. baemolytica isolates. Furthermore, Davies et al. (1991) and Ali et al. (1992) demonstrated that the LPS of bovine A1 isolates possessed $\mathrm{O}$-antigen side-chains, whereas that of ovine A2 isolates did not, an observation which suggested a possible correlation between LPS type and host specificity. Heterogeneity among A1 isolates was also described by Murphy et al. (1993) using restriction endonuclease analysis and ribotyping. These observations indicate that diversity does exist within the various serotypes of $P$. haemolytica and that a detailed investigation of this diversity is required to understand the reasons for the observed differences in host specificity and virulence.

The aim of the present study was to assess diversity within and examine relationships between the different serotypes of $P$. baemolytica by analysis of cell-surface components. Diversity was assessed by analysing variation in the capsular polysaccharide serotypes, LPS types and OMP profiles of $184 \mathrm{P}$. haemolytica isolates obtained from cattle and sheep from diverse geographical locations. The study focused on the biotype A serotypes of $P$. baemolytica but did not include the recently described serotype A17 (Younan \& Fodor, 1995). The relationships between untypable and biotype $\mathrm{A}$ isolates of $P$. baemolytica, and between these and $P$. trebalosi, have been examined by comparison of cell-surface components and 16S rRNA sequences and are described in a separate study (Davies $e t$ al., 1996). Intra-specific diversity within $P$. trebalosi has also been described in a previous study (Davies \& Quirie, 1996).

\section{METHODS}

Bacterial strains and growth conditions. One-hundred-andeighty-four isolates of $P$. baemolytica from widespread geographical areas were examined. The isolates originated from British Veterinary Investigation (VI) Centres (112), the culture collection at the University of Glasgow (17), the USA (18), Germany (17), the National Collection of Type Cultures (NCTC) (17) and the Moredun Research Institute (MRI) (3). The VI Centres included five in England, five in Scotland and two in Wales. Seventy-one isolates were recovered from cattle and 109 from sheep; four isolates were of unknown origin but probably originated from sheep.

Isolates from the MRI and VI Centres were submitted to Glasgow on blood agar slopes. At the VI Centres, field isolates were identified as $P$. baemolytica based on clinical diagnosis, colony morphology, Gram-staining and cell morphology, and preliminary biochemical characterization. Identity was confirmed at the MRI by capsular serotyping. Isolates from the USA, Germany and the NCTC collection were obtained in a freeze-dried state and revived by growing on sheep's blood agar (brain heart infusion agar containing $5 \%, v / v$, defibrinated sheep's blood) at $37^{\circ} \mathrm{C}$. Isolates were stored at $-70^{\circ} \mathrm{C}$ in $50 \%$ $(\mathrm{v} / \mathrm{v})$ glycerol in brain heart infusion broth (BHIB). For preparation of outer membranes, bacteria were streaked onto sheep's blood agar and grown overnight at $37^{\circ} \mathrm{C}$. A few colonies were inoculated into $500 \mathrm{ml}$ volumes of BHIB in 21 Erlenmeyer flasks and grown to late exponential phase $(6-7 \mathrm{~h})$ at $37^{\circ} \mathrm{C}$ with shaking at 120 r.p.m. (Davies et al., 1992). 
Serotyping. Capsular serotyping was carried out by the rapid indirect haemagglutination assay with bovine red blood cells as described by Fraser \& Donachie (1983).

Preparation of OMPs and LPS. OMPs were prepared by Sarkosyl extraction (Filip et al., 1973) as described previously (Davies et al., 1992). LPS was prepared by proteinase $\mathrm{K}$ digestion (Hitchcock \& Brown, 1983) of outer membranes as previously described (Davies et al., 1991, 1992).

Protein assay. The modified Lowry procedure of Markwell $e t$ al. (1978), specific for membrane proteins, was used to standardize the protein concentrations of the outer-membrane samples to $2 \cdot 0 \mathrm{mg} \mathrm{ml}^{-1}$.

SDSPAGE. OMPs and LPS were separated by SDS-PAGE using the SDS discontinuous system of Laemmli (1970) as described previously (Davies et al., 1992). OMPs were separated in $12 \%(\mathrm{w} / \mathrm{v})$ resolving gels and LPS in $15 \%(\mathrm{w} / \mathrm{v})$ resolving gels containing $4 \mathrm{M}$ urea. The protein molecular mass standards (Pharmacia) used were phosphorylase b $(94 \mathrm{kDa})$, bovine serum albumin $(67 \mathrm{kDa})$, ovalbumin $(43 \mathrm{kDa})$, carbonic anhydrase $(30 \mathrm{kDa})$, trypsin inhibitor $(20.1 \mathrm{kDa})$ and $\alpha$-lactalbumin $(14 \cdot 4 \mathrm{kDa})$. OMPs were visualized by staining with Coomassie Brilliant Blue and LPS by silver staining (Tsai \& Frasch, 1982). The molecular masses of individual proteins were estimated from calibration curves.

Western blotting of LPS. LPS gels were run as described above and Western blotting performed as described previously (Davies et al., 1994). The primary antiserum, used at a concentration of $1: 100$, was raised in a calf against live cells of a serotype A1 isolate possessing smooth LPS of type 1A (Ali et al., 1992).

\section{RESULTS}

\section{Association of capsular serotypes with cattle and sheep}

As expected, there were clear-cut differences in the isolation rates of the different capsular serotypes from cattle and sheep. The most common capsular serotypes were A1 and A2, each of which comprised $55(29.9 \%)$ isolates (see Table 2). However, most $(87 \cdot 3 \%$ ) of the A1 isolates originated from cattle, whereas most $(80 \%)$ of the A2 isolates originated from sheep. Serotype A6 isolates, of which there were $21(11.4 \%)$, were recovered from both cattle and sheep in roughly equal proportions from each species. In contrast, at least $19(90 \%)$ of the 21 serotype A7 isolates were recovered from sheep. The remaining eight serotypes were all associated with sheep and comprised 32 isolates or $17 \cdot 4 \%$ of the total.

\section{Analysis of LPS profiles}

The LPS profiles of 184 isolates of $P$. baemolytica were analysed by SDS-PAGE and silver-staining. Nine different profiles were identified which are shown in Fig. 1 (lanes 2-10). Differences occurred in the number and degree of expression of bands in the low-molecular-mass core-oligosaccharide region (Fig. 1a) and in the presence or absence of a ladder pattern in the high-molecular-mass region, indicating the presence or absence of $\mathrm{O}$-antigen side-chains (Fig. 1b, arrows). To demonstrate O-antigen side-chains, the LPS needed to be stained for 10-15 min, but after this length of time the resolution of individual bands in the core-oligosaccharide region was reduced due to overstaining (Fig. 1b). Optimum resolution of the core-oligosaccharide region was obtained when the gel was stained for only 5-7 min, but after this length of time the O-antigen side-chains were not visible (Fig. 1a). It should be noted that the ladder pattern of typical smoothtype LPS found in other bacteria, including $P$. trebalosi, was clearly visible after 5-7 min of staining (Fig. 1a, lane 1).

The LPS profiles could be differentiated into four types based on variation in the expression of six bands in the low-molecular-mass core-oligosaccharide region (Fig. 1a). These LPS types were designated 1-4 and are shown in lanes 2 and 3, 4 and 5, 6 and 7, and 8-10, respectively. Each LPS type could be further classified into one of two sub-types based on the presence or absence of $\mathrm{O}$-antigen side-chains (Fig. 1b). LPS possessing $\mathrm{O}$-antigen sidechains was classified as smooth and designated subtype A; LPS not possessing O-antigen side-chains was classified as rough and designated subtype $\mathrm{B}$. Thus, LPS types $1 \mathrm{~A}, 2 \mathrm{~A}, 3 \mathrm{~A}$ and $4 \mathrm{~A}$ (lanes 2, 4, 6 and 8, respectively) possessed $\mathrm{O}$-antigen side-chains, whereas LPS types $1 \mathrm{~B}$, 2B, 3B and 4B (lanes 3, 5, 7 and 9, respectively) did not. A ninth LPS type, designated type 4C, possessed a coreoligosaccharide region similar to that of LPS types $4 \mathrm{~A}$ and 4B (although there were minor differences; Fig. 1a, lanes 8-10) but differed in the appearance of the ladder pattern (Fig. 1b, lane 10). The ladder pattern of type 4C LPS was more extensive and stained more intensively than that of sub-type A LPS (compare lane 10 with lanes 2, 4, 6 and 8, arrows).

The immunological relationships between the different LPS types were examined by Western blotting using antiserum raised against an isolate possessing type $1 \mathrm{~A}$ LPS (Fig. 2). The O-antigen side-chains of LPS types $1 \mathrm{~A}$, 2A, $3 \mathrm{~A}$ and $4 \mathrm{~A}$ were immunologically identical since all reacted with the antiserum (lanes 1, 3, 5 and 7). The Oantigen side-chains of LPS type 4C did not react with the antiserum and were therefore immunologically unrelated (lane 9). The core-oligosaccharide regions of LPS types $1 \mathrm{~A}$ and $1 \mathrm{~B}$ were immunologically identical since they each gave identical reactions to the antiserum (lanes 1 and 2). The core-oligosaccharide regions of LPS types 2, 3 and 4 were immunologically different from that of LPS type 1 since there was a much less intense reaction in each case (lanes 3-9). However, the presence of weak crossreactivity indicated that certain epitopes were common to all four LPS types (lanes 3-9).

The relationships between the LPS types and capsular serotypes of the 184 isolates of $P$. baemolytica are summarized in Table 1. The serotypes could be sub-divided into four groups based on the dominant LPS types. Serotype A1, A6, A9, A12 and A5 isolates were characterized by possession of predominantly smooth type $1 \mathrm{~A}$ LPS; no other serotypes possessed this LPS type. Serotype A2, A8, A14 and A16 isolates possessed only rough type $1 B$ and 3B LPS; very few isolates of other serotypes possessed these LPS types. Serotype A7 and A13 isolates possessed primarily smooth type $3 \mathrm{~A}$ and $4 \mathrm{~A}$ and rough 
(a)

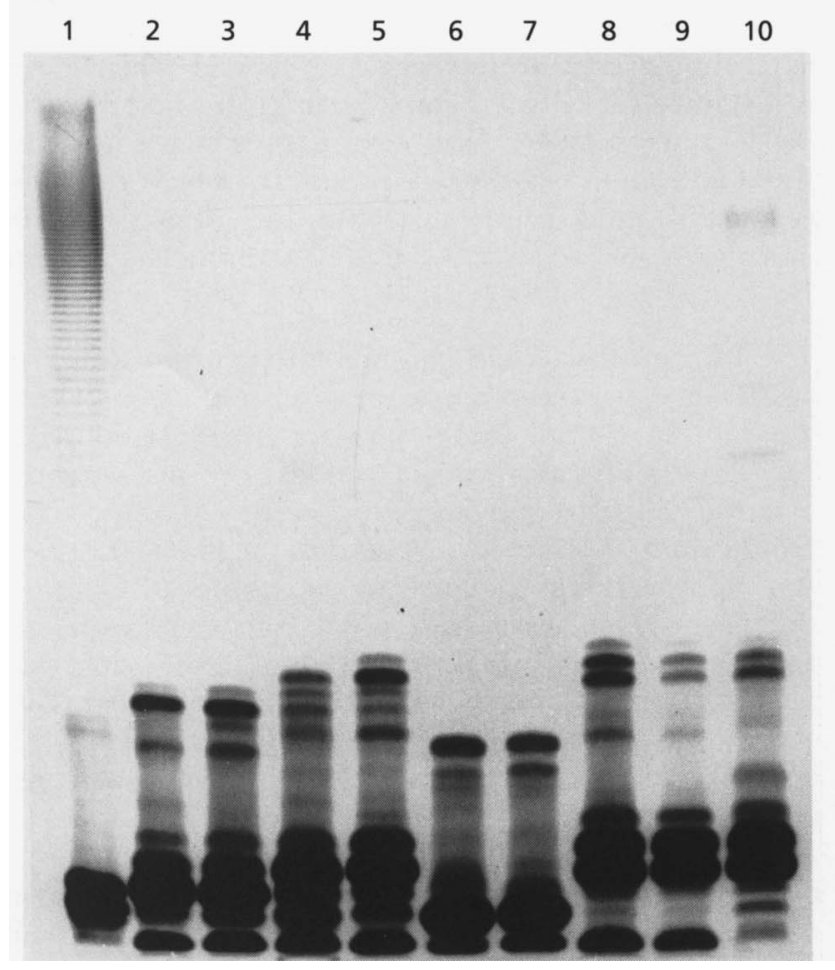

(b)

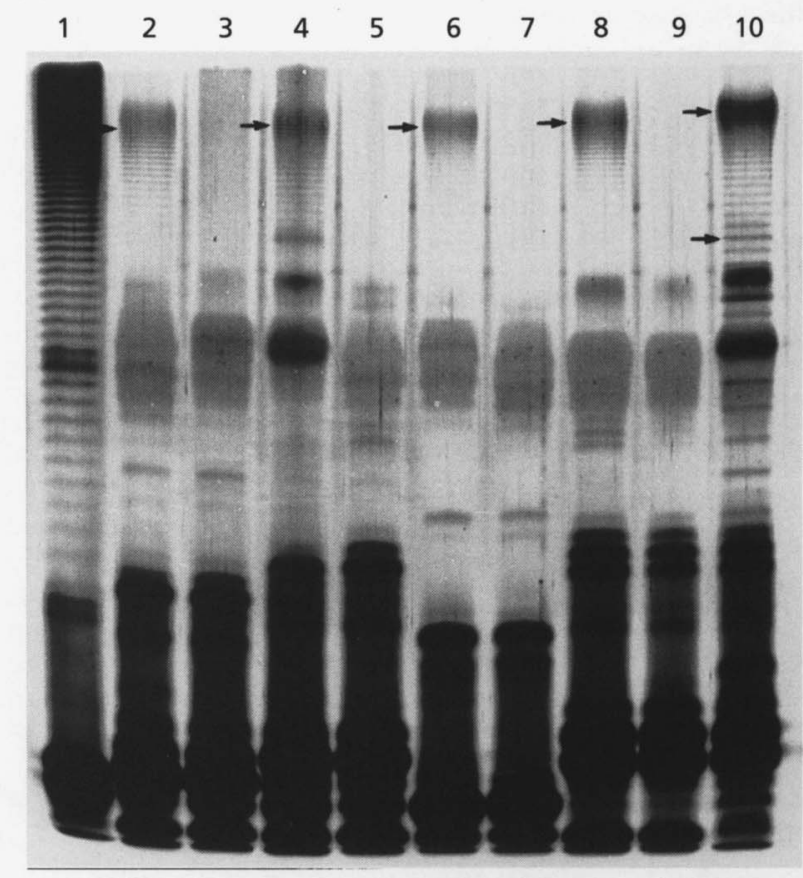

Fig. 1. Silver-stained LPS profiles of $P$. haemolytica LPS showing LPS types $1 A, 1 B, 2 A, 2 B, 3 A, 3 B, 4 A, 4 B$ and $4 C$ in lanes $2-10$, respectively. Smooth LPS of $P$. trehalosi is shown in lane 1. (a) LPS after 7 min of staining demonstrating optimum resolution of low-molecular-mass core-oligosaccharide into individual bands and differences between LPS types 1, 2, 3 and 4. (b) LPS after 15 min of staining demonstrating O-antigen side-chains (arrows) of LPS types 1A, 2A, 3A, 4A and 4C.

type 4B LPS; no other serotypes possessed LPS of types $4 \mathrm{~A}$ or 4B. Serotype A11 isolates possessed only smooth type 4C LPS; no other serotypes possessed this LPS type.

\section{Analysis of OMP profiles}

The OMP profiles of the 184 isolates of $P$. baemolytica were analysed by SDS-PAGE and the representative types are shown in Figs 3-5. The profiles were typical of those of Gram-negative bacteria, consisting of 3-4 major proteins and 15-20 minor proteins. The OMP profiles could be differentiated into types and sub-types based essentially on variation of the following groups of proteins: (1) 2-3 major proteins in the molecular mass range $39-41 \mathrm{kDa}$; (2) a major protein in the molecular mass range $30.5-31 \mathrm{kDa}$; (3) proteins of 34 and $35 \mathrm{kDa}$; (4) highmolecular-mass proteins in the range $65-100 \mathrm{kDa}$; (5) low-molecular-mass proteins in the range $16-17 \mathrm{kDa}$. Based on variation of their OMP profiles, the serotypes could be sub-divided into three main groups, the main features of each being summarized below and in Table 2 .

Serotype A1, A6, A9, A12, A5 and A8 isolates. The profiles of this group were characterized by possession of 39,40 and $41 \mathrm{kDa}$ major proteins, of which the 39 and $41 \mathrm{kDa}$ proteins were expressed more abundantly than the $40 \mathrm{kDa}$ protein (Fig. 3). The A1 profiles could be differentiated into two sub-groups designated OMP types 1.1 and 1.2
(Fig. 3a). OMP type 1.1 (lanes 1-6) possessed a $31 \mathrm{kDa}$ major protein, 31.5 and $65 \mathrm{kDa}$ minor proteins, and had enhanced expression of a $90 \mathrm{kDa}$ protein (lane 1, upper four arrows); OMP type 1.2 (lanes 7-10) possessed a $30.5 \mathrm{kDa}$ major protein, lacked 31.5 and $65 \mathrm{kDa}$ minor proteins and had reduced expression of the $90 \mathrm{kDa}$ protein. OMP type 1.1 could be further divided into three sub-types, designated OMP types 1.1.1 (lanes 1 and 2), 1.1.2 (lanes 3 and 4) and 1.1.3 (lanes 5 and 6), based on variation in the molecular mass of the $90 \mathrm{kDa}$ protein (lane 3, arrow) or $31 \mathrm{kDa}$ major and $31.5 \mathrm{kDa}$ minor proteins (lane 5, arrows). Similarly, OMP type 1.2 could be divided into two sub-types, designated OMP types 1.2.1 (lanes 7 and 8) and 1.2.2 (lanes 9 and 10), based on variation in expression of a $49 \mathrm{kDa}$ minor protein (lane 9 , arrow). Variation also occurred in the molecular mass of two low-molecular-mass $(16-17 \mathrm{kDa})$ proteins in some isolates (lane 1, lower arrows) but, with the exception of the two isolates of OMP type 1.1.2 (lanes 3 and 4), this variation was not related to a particular OMP type. Details of the LPS types, OMP types and host species of the A1 isolates are given in Table 2. Significantly, type 1.1 profiles were associated only with bovine isolates and type 1.2 profiles only with ovine isolates (Table 2 ).

The profiles of the A6 isolates (Fig. $3 \mathrm{~b}$ ) were very similar to the $A 1$ profiles and could likewise be divided into two sub-groups based on possession of a 30.5 or $31 \mathrm{kDa}$ major 


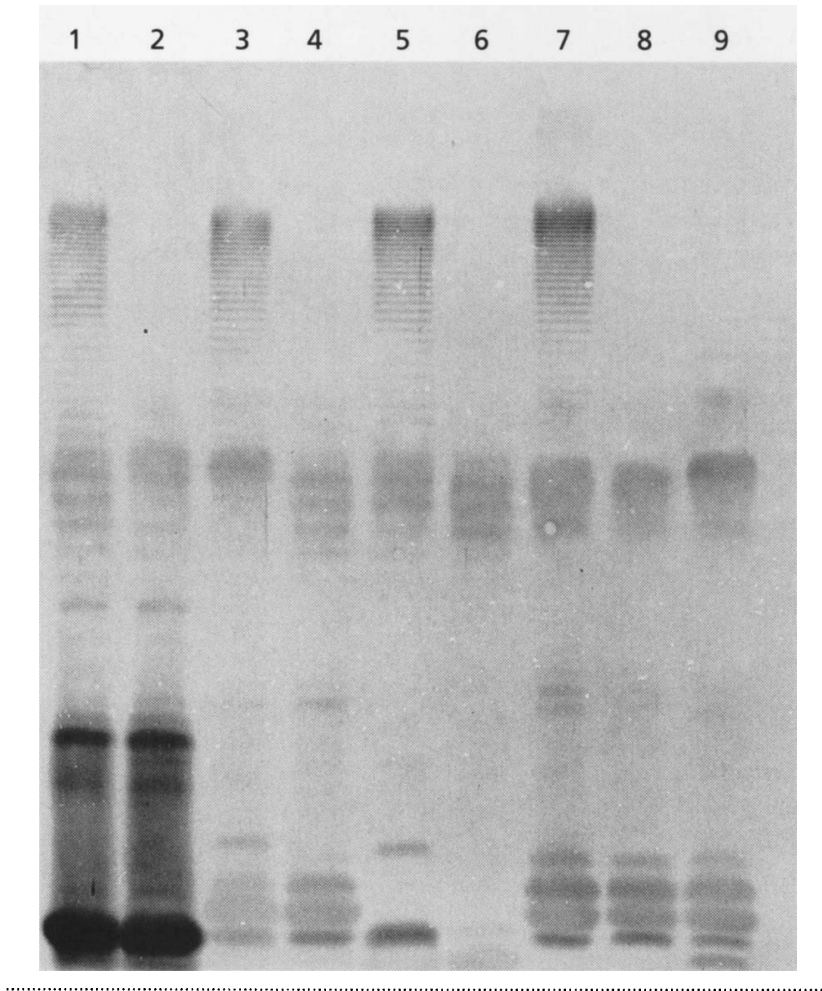

Fig. 2. Western-blot showing reaction of anti-type $1 A$ LPS antiserum against $L P S$ types 1A, 1B, 2A, 2B, 3A, 3B, 4A, 4B and $4 C$ (lanes 1-9). The ladder-patterns of the $O$-antigen side-chains of LPS types 1A, 2A, 3A and 4A (lanes 1, 3, 5 and 7, respectively), and identical reactions of core-oligosaccharide region of LPS types 1A and 1B (lanes 1 and 2, respectively), are clearly seen, indicating immunological identity.

Table 1. Association of LPS types with capsular serotypes in $P$. haemolytica

\begin{tabular}{|c|c|c|c|c|c|c|c|c|c|c|}
\hline \multirow{2}{*}{$\begin{array}{l}\text { Capsular } \\
\text { serotype* }\end{array}$} & \multirow{2}{*}{$\begin{array}{l}\text { No. of } \\
\text { isolates }\end{array}$} & \multicolumn{9}{|c|}{ LPS type } \\
\hline & & $1 \mathbf{A}$ & $1 B$ & $2 A$ & $2 B$ & $3 \mathbf{A}$ & $3 B$ & $4 A$ & $4 B$ & $4 C$ \\
\hline \multicolumn{11}{|l|}{ Group 1} \\
\hline A1 & 55 & 48 & 2 & 4 & - & 1 & - & - & - & - \\
\hline A6 & 21 & 16 & 1 & 3 & 1 & - & - & - & - & - \\
\hline A9 & 8 & 7 & - & - & - & 1 & - & - & - & - \\
\hline A 12 & 6 & 5 & 1 & - & - & - & - & - & - & - \\
\hline A5 & 3 & 3 & - & - & - & - & - & - & - & - \\
\hline \multicolumn{11}{|l|}{ Group 2} \\
\hline $\mathrm{A} 2$ & 55 & - & 26 & - & - & - & 29 & - & - & - \\
\hline A8 & 2 & - & 2 & - & - & - & - & - & - & - \\
\hline A14 & 1 & - & 1 & - & - & - & - & - & - & - \\
\hline A16 & 1 & - & 1 & - & - & - & - & - & - & - \\
\hline \multicolumn{11}{|l|}{ Group 3} \\
\hline A7 & 21 & - & 2 & - & - & 4 & 2 & 10 & 3 & - \\
\hline A13 & 4 & - & - & - & - & - & - & 4 & - & - \\
\hline \multicolumn{11}{|l|}{ Group 4} \\
\hline A11 & 7 & - & - & - & - & - & - & - & - & 7 \\
\hline
\end{tabular}

* Groups 1-4 are based on the dominant LPS types (in bold) within each capsular serotype.
Table 2. Details of isolates of $P$. haemolytica examined in the study

\begin{tabular}{|c|c|c|c|c|}
\hline Serotype* & $\begin{array}{l}\text { LPS } \\
\text { type }\end{array}$ & $\begin{array}{c}\text { OMP } \\
\text { type }\end{array}$ & $\begin{array}{c}\text { Host } \\
\text { species }\end{array}$ & $\begin{array}{l}\text { No. of } \\
\text { isolates }\end{array}$ \\
\hline \multicolumn{5}{|l|}{ Group 1} \\
\hline \multirow[t]{8}{*}{ A1 } & $1 \mathrm{~A}$ & 1.1 .1 & Bovine & 42 \\
\hline & $2 \mathrm{~A}$ & 1.1 .1 & Bovine & 2 \\
\hline & $1 \mathrm{~A}$ & 1.1 .2 & Bovine & 2 \\
\hline & $2 \mathrm{~A}$ & 1.1 .3 & Bovine & 2 \\
\hline & $1 \mathrm{~A}$ & 1.2 .1 & Ovine & 3 \\
\hline & $1 \mathrm{~B}$ & 1.2 .1 & Ovine & 2 \\
\hline & $1 \mathrm{~A}$ & 1.2 .2 & Ovine & 1 \\
\hline & $3 \mathrm{~A}$ & 1.2 .2 & Ovine & 1 \\
\hline \multirow[t]{7}{*}{ A6 } & $1 \mathrm{~A}$ & 1.1 .4 & Bovine & 10 \\
\hline & $1 \mathrm{~B}$ & 1.1 .4 & Bovine & 1 \\
\hline & $2 \mathrm{~A}$ & 1.1 .4 & Bovine & 1 \\
\hline & $1 \mathrm{~A}$ & 1.1 .4 & Ovine & 1 \\
\hline & $1 \mathrm{~A}$ & 1.2 .3 & Ovine & 5 \\
\hline & $2 \mathrm{~A}$ & 1.2 .3 & Ovine & 2 \\
\hline & $2 B$ & 1.2 .3 & Ovine & 1 \\
\hline \multirow[t]{2}{*}{ A9 } & $1 \mathrm{~A}$ & 1.2 .3 & Ovine & 7 \\
\hline & $3 \mathrm{~A}$ & 1.2 .3 & Ovine & 1 \\
\hline \multirow[t]{2}{*}{$\mathrm{A} 12$} & $1 \mathrm{~A}$ & 1.2 .3 & Ovine & 5 \\
\hline & $1 \mathrm{~B}$ & 1.2 .3 & Ovine & 1 \\
\hline A5 & $1 \mathrm{~A}$ & 1.2 .3 & Ovine & 3 \\
\hline A8 & $1 \mathrm{~B}$ & 1.2 .3 & Ovine & 2 \\
\hline \multicolumn{5}{|l|}{ Group 2} \\
\hline \multirow[t]{11}{*}{ A2 } & $1 \mathrm{~B}$ & 2.1 .1 & Bovine & 2 \\
\hline & $3 B$ & 2.1 .2 & Bovine & 5 \\
\hline & $3 B$ & 2.1 .3 & Bovine & 2 \\
\hline & $3 B$ & 2.1 .4 & Bovine & 2 \\
\hline & $1 \mathrm{~B}$ & 2.2 .1 & Ovine & 20 \\
\hline & $3 B$ & 2.2 .1 & Ovine & 2 \\
\hline & $1 \mathrm{~B}$ & 2.2 .2 & Ovine & 2 \\
\hline & $3 B$ & 2.2 .2 & Ovine & 16 \\
\hline & $1 \mathrm{~B}$ & 2.2 .3 & Ovine & 1 \\
\hline & $3 B$ & 2.2 .3 & Ovine & 1 \\
\hline & $3 B$ & 2.2 .4 & Ovine & 2 \\
\hline A14 & $1 \mathrm{~B}$ & 2.3 .1 & Ovine & 1 \\
\hline A16 & $1 \mathrm{~B}$ & 2.3 .1 & Ovine & 1 \\
\hline \multicolumn{5}{|l|}{ Group 3} \\
\hline \multirow[t]{9}{*}{ A7 } & $4 \mathrm{~A}$ & 3.1 .1 & Ovine & 9 \\
\hline & $4 B$ & 3.1 .1 & Ovine & 2 \\
\hline & $4 \mathrm{~A}$ & 3.1 .2 & Ovine & 1 \\
\hline & $4 B$ & 3.1 .2 & Ovine & 1 \\
\hline & $3 \mathrm{~A}$ & 1.2 .1 & Ovine & 4 \\
\hline & $1 \mathrm{~B}$ & 1.2 .1 & Ovine & 1 \\
\hline & $1 \mathrm{~B}$ & 2.1 .1 & Ovine & 1 \\
\hline & $3 B$ & 2.1 .2 & Ovine & 1 \\
\hline & $3 B$ & 2.2 .2 & - & 1 \\
\hline \multirow[t]{2}{*}{ A11 } & $4 C$ & 3.2 .1 & Ovine & 2 \\
\hline & $4 C$ & 3.2 .2 & Ovine & 5 \\
\hline \multirow[t]{2}{*}{ A13 } & $4 \mathrm{~A}$ & 3.3.1 & Ovine & 1 \\
\hline & $4 \mathrm{~A}$ & 3.3.2 & Ovine & 3 \\
\hline
\end{tabular}

* Groups 1-3 are based on the dominant OMP profiles within each capsular serotype. 
(a)

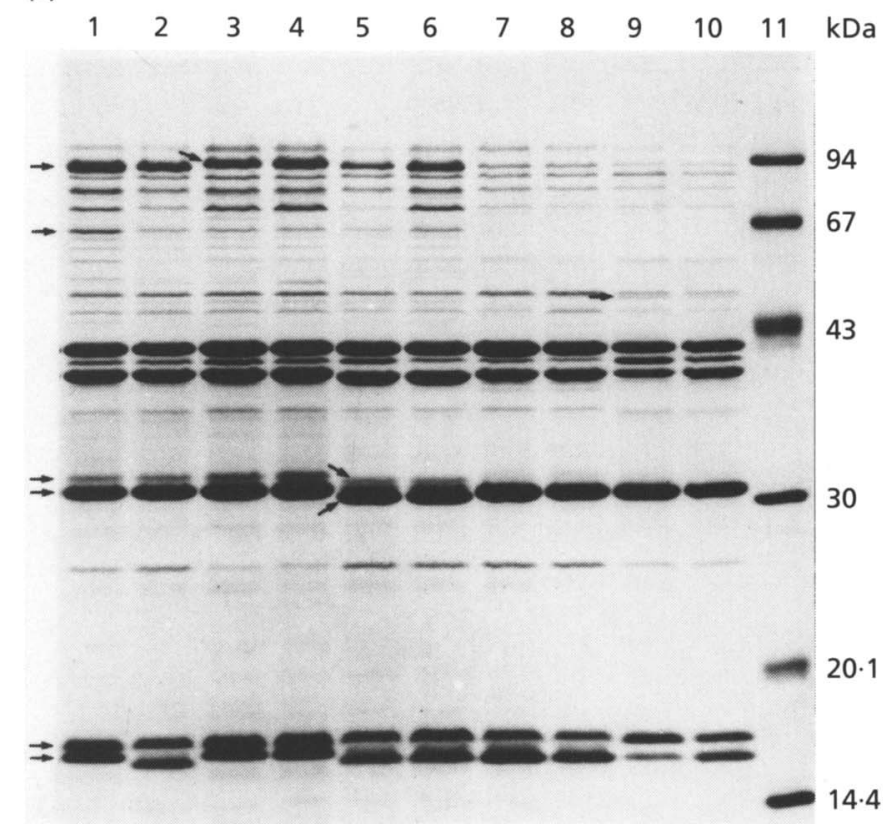

(b)

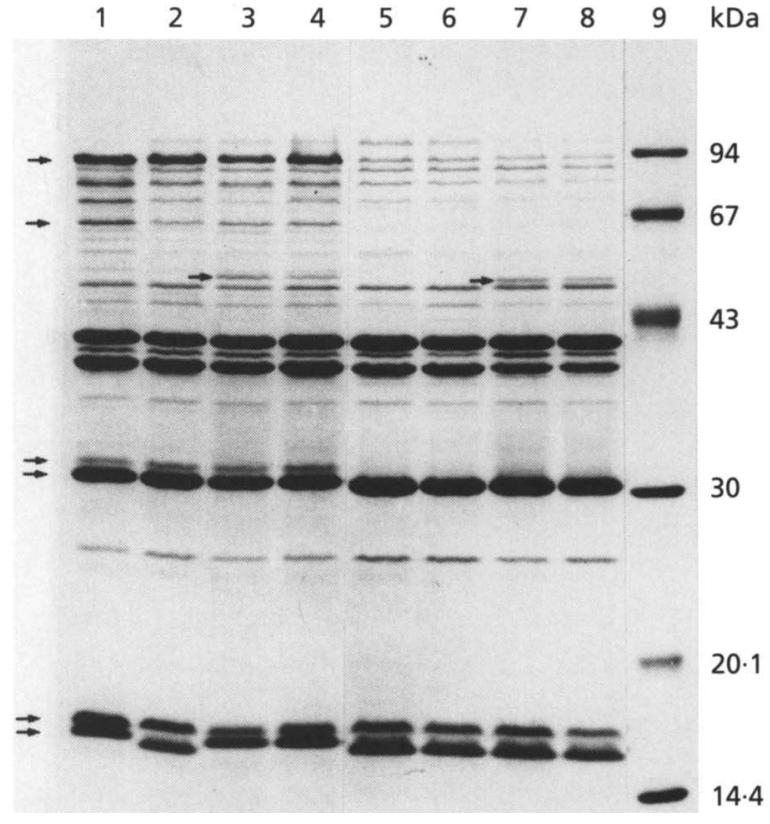

Fig. 3. OMP profiles of (a) serotype $A 1$ and (b) serotype $A 6$ isolates of $P$. haemolytica. (a) shows type 1.1 .1 (lanes 1 and 2 ), 1.1.2 (lanes 3 and 4), 1.1.3 (lanes 5 and 6), 1.2.1 (lanes 7 and 8) and 1.2.2 (lanes 9 and 10) profiles of serotype A1 isolates. (b) shows type 1.1.4 (lanes 3 and 4) and 1.2.3 (lanes 7 and 8) profiles of serotype A6 isolates. For comparison, profiles of serotype $A 1$ isolates of OMP types 1.1 .1 and 1.2 .1 are shown in lanes 1 and 2 , and 5 and 6 , respectively. Molecular mass standards (kDa) are shown in lanes 11 (a) and 9 (b). Arrows are explained in the text.

protein, 31.5 and $65 \mathrm{kDa}$ minor proteins, and the degree of expression of the $90 \mathrm{kDa}$ protein (lane 1, upper four arrows). The A6 profiles were designated OMP types 1.1.4 (lanes 3 and 4 ) and 1.2.3 (lanes 7 and 8); they differed from the A1 profiles in that minor proteins of $53 \mathrm{kDa}$ (lane 3, arrow) and $51 \mathrm{kDa}$ (lane 7, arrow) were expressed in A6 but not in A1 isolates. A1 profiles of types 1.1.1 (lanes 1 and 2) and 1.2.1 (lanes 5 and 6) are shown for comparison. The type 1.1.4 (lanes 3 and 4) and 1.2.3 (lanes 7 and 8 ) profiles also differed in the mobilities of the two low-molecular-mass proteins (lane 1, lower arrows). Details of the A6 isolates are given in Table 2. Again, as with the A1 isolates, type 1.1 and 1.2 profiles were associated only with bovine (with one exception) and ovine isolates, respectively (Table 2).

The profiles of the A9, A12, A5 and A8 isolates, which were all of ovine origin, were uniformally similar to each other and to the type 1.2.3 profile of ovine A6 isolates (results not shown). The possession of a 30.5 rather than a $31 \mathrm{kDa}$ major protein, absence of 31.5 and $65 \mathrm{kDa}$ proteins, and less abundant expression of the $90 \mathrm{kDa}$ protein distinguished these profiles from the type 1.1 profiles of bovine $\mathrm{A} 1$ and $\mathrm{A} 6$ isolates. The possession of a $51 \mathrm{kDa}$ minor protein, which was also present in the type 1.2.3 profile of ovine $\mathrm{A} 6$ isolates, distinguished these profiles from the type 1.2.1 and 1.2.2 profiles of ovine A1 isolates. Details of the A9, A12, A5 and A8 isolates are given in Table 2.

Serotype A2, A14 and A16 isolates. The profiles of this group differed from those of the A1 group in having only two proteins in the $39-41 \mathrm{kDa}$ range (Fig. 4). The A2 profiles could also be differentiated in terms of bovine (Fig. 4a) and ovine (Fig. 4b) isolates. Bovine A2 isolates differed from ovine isolates in the possession of a 31 rather than a $30.5 \mathrm{kDa}$ major protein and in the presence of a minor $31.5 \mathrm{kDa}$ protein (Fig. $4 \mathrm{a}$, lane 2 , second and third arrows from bottom), differences also observed between bovine and ovine $\mathrm{A} 1$ and $\mathrm{A} 6$ isolates. Four distinct OMP profiles were identified within the bovine A2 isolates (Fig. 4a) which were designated OMP types 2.1.1 (lanes 2 and 3), 2.1.2 (lanes 4 and 5), 2.1.3 (lanes 6 and 7) and 2.1.4. (lanes 8 and 9). OMP type 2.1.1 (lanes 2 and 3) was characterized by possessing a $17.5 \mathrm{kDa}$ protein (lane 2 , lower arrow); expression of the other two low-molecularmass proteins also differed. In addition, the two major proteins in the $39-41 \mathrm{kDa}$ range (lane 1 , arrows) were closer together than in OMP types 2.1.2 and 2.1.3 (compare lanes 2 and 3 with lanes 4-7). Differences also existed in the mobilities of high-molecular-mass proteins (compare lanes 2 and 4, upper arrows). OMP types 2.1.2 (lanes 4 and 5) and 2.1.3 (lanes 6 and 7) were very similar but differed in the mobility of the $41 \mathrm{kDa}$ major protein (lane 7 , arrow); there was also variation in highmolecular-mass proteins and OMP type 2.1.3 lacked a minor protein directly below the $30.5 \mathrm{kDa}$ major protein (lane 5, arrow). OMP type 2.1.4 (lanes 8 and 9) was easily differentiated from the others because of the distinctive shift in molecular mass of the $41 \mathrm{kDa}$ protein to $39 \cdot 5 \mathrm{kDa}$ (lane 9, arrow). The mobilities and expression of high- 
(a)

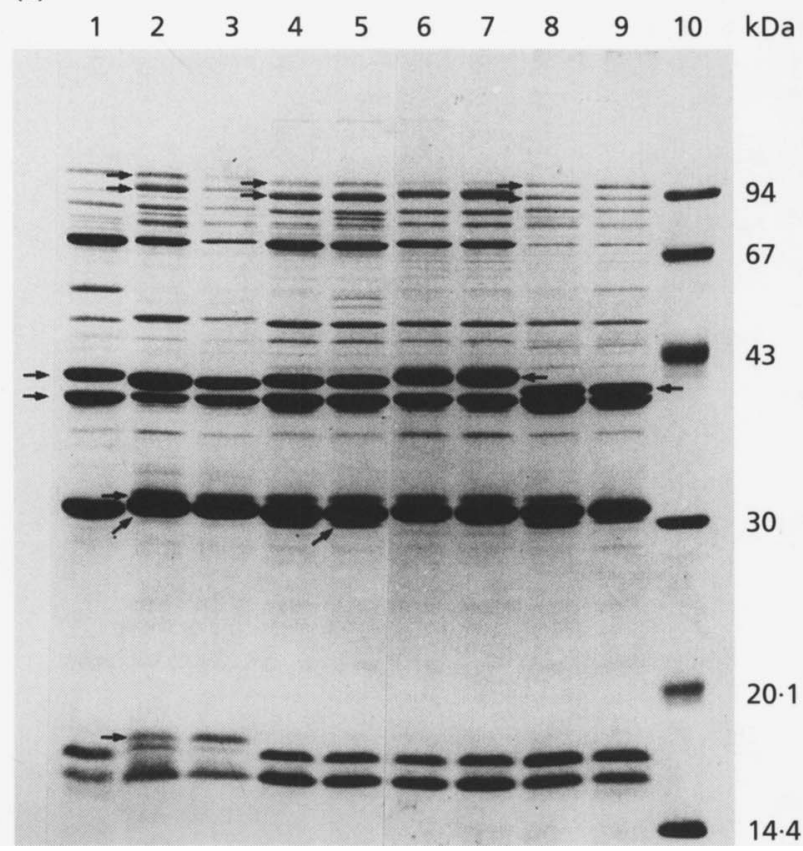

(b)

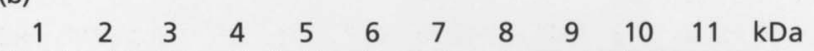

Fig. 4. OMP profiles of (a) bovine and (b) ovine serotype A2 isolates of $P$. haemolytica. (a) shows type 2.1 .1 (lanes 2 and 3), 2.1.2 (lanes 4 and 5), 2.1.3 (lanes 6 and 7) and 2.1.4 (lanes 8 and 9) profiles of bovine A2 isolates. For comparison, the profile of an ovine A2 isolate of OMP type 2.2.2 is shown in lane 1. (b) shows type 2.2.1 (lanes 3 and 4), 2.2.2 (lanes 5 and 6), 2.2.3 (lanes 7 and 8 ) and 2.2.4 (lanes 9 and 10) OMP profiles of ovine A2 isolates. For comparison, profiles of bovine A2 isolates of OMP types 2.1.1 and 2.1.2 are shown in lanes 1 and 2, respectively. Molecular mass standards (kDa) are shown in lanes 10 (a) and 11 (b). Arrows are explained in the text.

molecular-mass proteins in the range $67-100 \mathrm{kDa}$ were also different from those of the other OMP types (lane 8, arrows).

Ovine A2 isolates (Fig. 4b) formed two major groups possessing profiles of types 2.2 .1 (lanes 3 and 4 ) and 2.2.2 (lanes 5 and 6). These differed primarily in the expression of proteins of $57 \cdot 5,71$ and $77 \cdot 5 \mathrm{kDa}$ (lane 5 , arrows). OMP types 2.2.1 and 2.2.2 possessed major proteins of 39 and $41 \mathrm{kDa}$, whereas two further OMP types, 2.2 .3 (lanes 7 and 8) and 2.2.4 (lanes 9 and 10), possessed major proteins of 39 and $40.5 \mathrm{kDa}$ (lane 7 , arrow). Variation in the $40 \cdot 5 / 41 \mathrm{kD}$ a protein was the only significant difference between OMP types 2.2.1 and 2.2.3 (compare lanes 3 and 4 with lanes 7 and 8). OMP type 2.2.4 was similar to OMP type 2.2.3 with the exception that there was a slight shift in the molecular mass of the $30.5 \mathrm{kDa}$ protein to approximately $31 \mathrm{kDa}$, and an additional $31.5 \mathrm{kDa}$ minor protein was present (lane 9, lower arrows). This difference resembled that between bovine and ovine A1 and A6 isolates. There was also a shift in the mobility of a highmolecular-mass (approximately $100 \mathrm{kDa}$ ) protein (lane 9 , upper arrow). Details of the $\mathrm{A} 2$ isolates are given in Table 2.

The single isolates of serotypes A14 and A16 possessed similar OMP profiles which resembled those of serotype A2 isolates (results not shown), the main feature being the absence of a $40 \mathrm{kDa}$ protein. The profiles, which differed from those of A2 isolates in the mobilities of the $41 \mathrm{kDa}$ protein and possession of a $25 \mathrm{kDa}$ minor protein, were designated OMP type 2.3.1 (Table 2).

Serotype A7, A11 and A13 isolates. The profiles of this group of ovine isolates were characterized by the expression of two novel 34 and $35 \mathrm{kDa}$ proteins (Fig. 5). Like ovine isolates of the previous two groups, isolates within this group were characterized by possession of a $30.5 \mathrm{kDa}$ major protein, absence of 31.5 and $65 \mathrm{kDa}$ minor proteins and reduced expression of a $90 \mathrm{kDa}$ protein (Fig. 5a, lanes 1 and 2, arrows). The profiles of A7 isolates were more varied than those of the $A 1$ and $A 2$ groups, seven distinct profiles occurring among only 21 isolates (Fig. 5a). Profiles within this group resembled those of both the A1 and A2 groups. Eleven isolates possessed the profile shown in lanes 3 and 4 , designated OMP type 3.1.1. This profile resembled those of the A1 and $A 6$ profiles 1.2.1 (lane 2), 1.2.2 and 1.2.3 but differed in the possession of the 34 and $35 \mathrm{kDa}$ proteins (lane 3 , upper two arrows) and in the mobilities and expression of the two low-molecular-mass proteins (lane 3, lower arrow). Two isolates possessed the profile shown in lanes 5 and 6, designated OMP type 3.1.2. This profile differed from that of type 3.1.1 in the expression and/or mobilities of the two major 40 and $41 \mathrm{kDa}$ proteins (lanes 4 and 5, arrows). Five isolates possessed profiles similar to the type 1.2.1 profile of serotype A1 isolates (lanes 7-9), although variation occurred in the expression of the $40 \mathrm{kDa}$ protein (lane 7, arrow). The remaining three isolates possessed profiles similar to those of serotype A2 isolates and were 
(a)

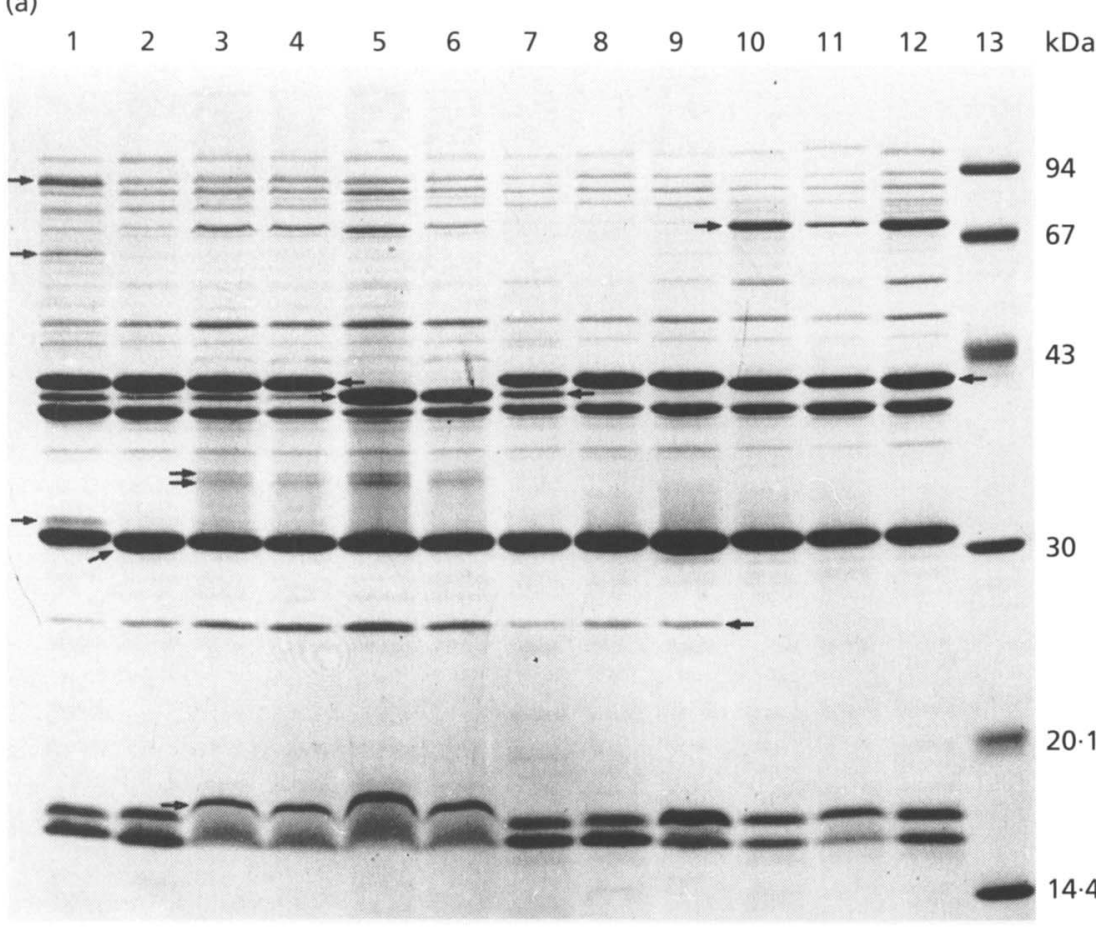

$\begin{array}{llllllllllllll}\text { (b) } & & & & & & & & & & & & & \end{array}$

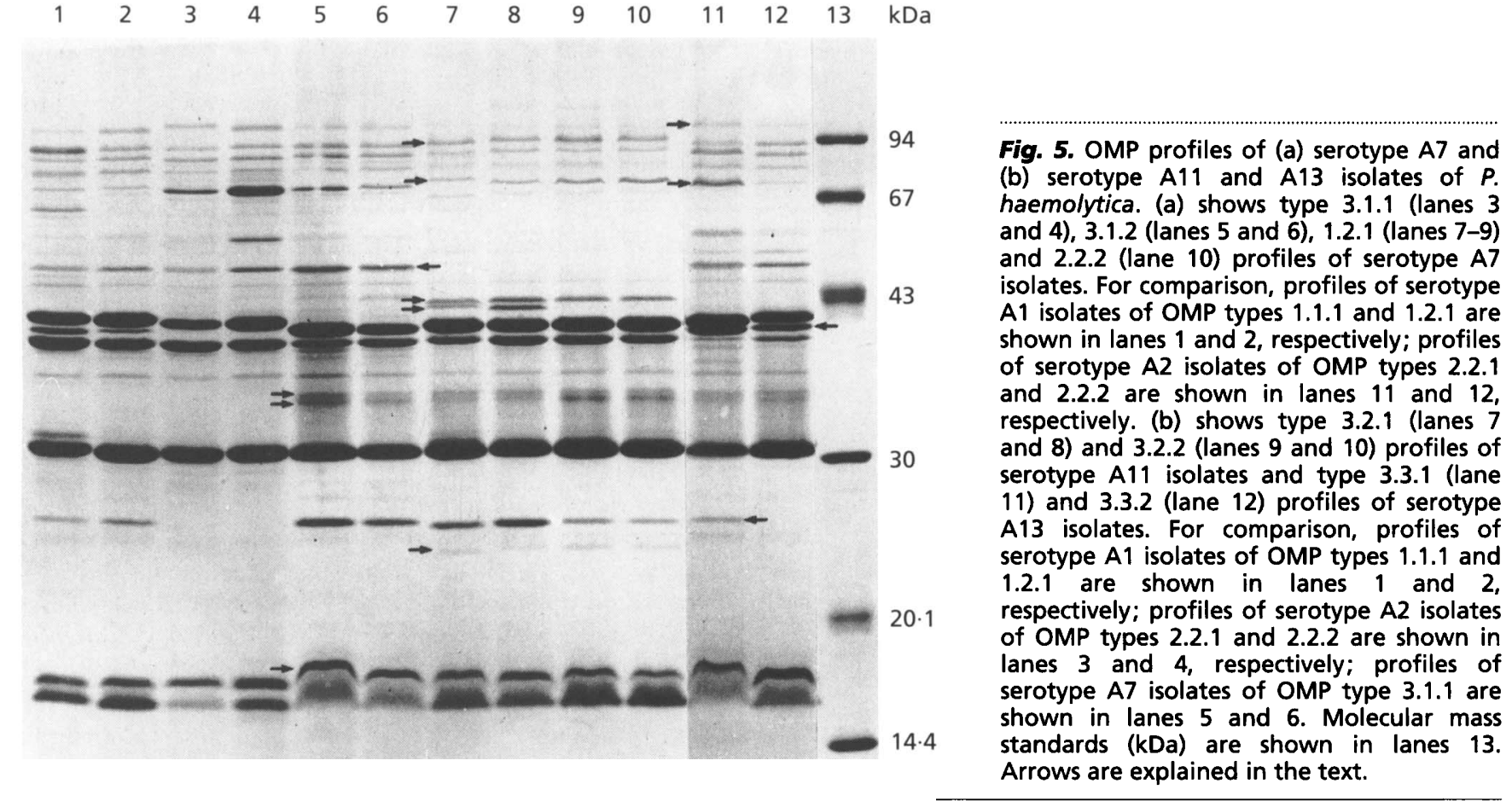

assigned the A2 OMP types 2.1.2, 2.2.1 and 2.2.2. The A7 type 2.2 .2 profile is shown in lane 10 and the A2 type 2.2 .1 and 2.2.2 profiles are shown in lanes 11 and 12 for comparison. As can be seen, the profiles in lanes 10 and 12 have similar expression of the $71 \mathrm{kDa}$ protein (lane 10 , arrow), similar mobilities of the $41 \mathrm{kDa}$ protein (lane 12 , arrow) and lack a $25 \mathrm{kDa}$ protein (lane 9, arrow). Details of the A7 isolates are given in Table 2.
Fig. 5. OMP profiles of (a) serotype $A 7$ and (b) serotype $A 11$ and $A 13$ isolates of $P$. (a) shows type 3.1.1 (lanes 3 and 13.1 .2 (lanes 5 and 6 ), 1.2. (lanes 7-9) isolates. For comparison, profiles of serotype A1 isolates of OMP types 1.1.1 and 1.2.1 are shown in lanes 1 and 2, respectively; profiles of serotype A2 isolates of OMP types 2.2.1 and 2.2.2 are shown in lanes 11 and 12, respectively. (b) shows type 3.2.1 (lanes 7 and 8) and 3.2.2 (lanes 9 and 10) profiles of serotype A11 isolates and type 3.3.1 (lane 11) and 3.3.2 (lane 12) profiles of serotype A13 isolates. For comparison, profiles of serotype A1 isolates of OMP types 1.1.1 and 1.2.1 are shown in lanes 1 and 2 , respectively; profiles of serotype $A 2$ isolates of OMP types 2.2.1 and 2.2.2 are shown in lanes 3 and 4, respectively; profiles of serotype A7 isolates of OMP type 3.1.1 are shown in lanes 5 and 6 . Molecular mass Arrows are explained in the text. 
Table 3. The major clonal groups of $P$. haemolytica based on capsular serotypes, LPS types and OMP types

\begin{tabular}{|lcclc|}
\hline Serotype & $\begin{array}{c}\text { LPS } \\
\text { type }\end{array}$ & $\begin{array}{c}\text { OMP } \\
\text { type }\end{array}$ & $\begin{array}{c}\text { Host } \\
\text { species }\end{array}$ & $\begin{array}{c}\text { No. of } \\
\text { isolates }\end{array}$ \\
\hline A1 & 1A & 1.1 .1 & Bovine & 42 \\
A6 & 1A & 1.1 .4 & Bovine & 10 \\
A6 & 1A & 1.2 .3 & Ovine & 5 \\
A9 & 1A & 1.2 .3 & Ovine & 7 \\
A2 & 1B & 2.2 .1 & Ovine & 20 \\
A2 & 3B & 2.2 .2 & Ovine & 16 \\
A7 & 4A & 3.1 .1 & Ovine & 9 \\
\hline
\end{tabular}

profiles were designated types 3.2 .1 (lanes 7 and 8) and 3.2.2 (lanes 9 and 10) which differed in the expression of a $42 \mathrm{kDa}$ minor protein (lane 7 , lower arrow of middle pair). Details of the A11 isolates are given in Table 2.

The A13 profiles (Fig. 5b, lanes 11 and 12) were similar to the A7 type 3.1.1 and 3.1.2 profiles (Fig. 5a, lanes 3 and 4, and 5 and 6 ) and to the A11 type 3.2.1 and 3.2.2 profiles (Fig. 5b, lanes 7-10) in their expression of the 34 and $35 \mathrm{kDa}$ proteins (lane 5, upper arrows) and in the mobilities of the $16-17 \mathrm{kDa}$ proteins (lane 5, lower arrow). However, the A13 profiles differed from the A7 and $A 11$ profiles in the expression and mobilities of the 39-41 kDa major proteins (Fig. 5b, lane 12, arrow) and in the expression of high-molecular-mass proteins (lane 11, upper arrows) and were designated OMP types 3.3.1 (lane 11) and 3.3.2 (lane 12, arrow). OMP types 3.3.1 and 3.3.2 differed in the expression and mobilities of the $39-41 \mathrm{kDa}$ major proteins (lane 12) and in the expression of the $25 \mathrm{kDa}$ protein (lane 11, lower arrow). Details of the serotype A13 isolates are given in Table 2.

\section{Clonal relationships}

Analysis of capsular serotypes, LPS types and OMP profiles identified seven major groups of $P$. baemolytica isolates which probably represent five distinct clones and two groups of sub-clones marked by their respective serotype/LPS/OMP combinations (Table 3). Bovine A1 and A6 isolates probably represent two closely related, bovine-specific sub-clones differing mainly in capsule expression and together forming a distinct clonal group. Ovine A6 and A9 isolates may also represent two closely related, ovine-specific sub-clones differing mainly in capsule expression and also forming a clonal group. The two groups of A2 isolates could be differentiated in terms of both their LPS types and OMP profiles and probably represent two discrete clonal groups with specificity for sheep. These clones differed from the A1/A6 and A6/A9 clones in terms of their capsular polysaccharides, LPS types and OMP profiles, as well as by differences in host specificity in the case of the A1/A6 clone. The A7 isolates represent the fifth major clonal group which is characterized by having a unique capsular polysaccharide, LPS type and OMP profile. Like the A2 clones, it was recovered only from sheep, although it was not as abundant as the A2 clones. The seven clonal groups accounted for $109(59 \%)$ of the total number of isolates examined, thus representing a majority of the disease isolates.

\section{DISCUSSION}

\section{Association of capsular serotypes with cattle and sheep}

The majority of isolates examined were obtained over a 12 month period from British VI Centres and were recovered from cases of natural infections in cattle and sheep. The overall incidence of the various serotypes was representative of the situation in the UK and agrees with previous observations (Gilmour \& Gilmour, 1989). The isolation rates of the different serotypes clearly indicated that a wider range of serotypes is associated with sheep than cattle, but that serotypes $\mathrm{A} 1$ and $\mathrm{A} 2$ are the dominant pathogens in cattle and sheep, respectively (Table 2 ). The reasons for the observed frequency of association of each of the serotypes with disease in cattle or sheep is unknown and suggests differences in host specificity and virulence between the different serotypes. In previous studies, Gilmour et al. (1986) were unable to demonstrate differences in virulence among isolates of serotypes $\mathrm{A} 1$, A2, A7 and A9 in sheep. Furthermore, Gentry et al. (1988) were unable to identify major differences between six isolates of $P$. baemolytica, including five of serotypes A1, A2, A5, A6 and A9, together with an untypable isolate, which could account for differences in virulence. However, in both of the above studies only single representative isolates of individual serotypes were examined. As is clearly evident from the present study, such randomly chosen isolates are not necessarily representative of their respective serotypes and would not necessarily reflect differences in virulence, particularly if the isolates originated from the same host species and possessed similar LPS type and OMP profiles.

\section{LPS profiles}

$P$. baemolytica LPS is unusual in that rough and smooth forms occur independently in different isolates of the same species. A second unusual feature, which has been described previously (Davies et al., 1991; Lacroix et al., 1993), is that the O-antigen side-chains of $P$. baemolytica LPS do not stain as readily as those of the LPS of other species. These characteristics have also been observed in Campylobacter jejuni, in which both rough and smooth LPS forms occur and in which high-molecular-mass bands were not detectable by silver-staining (Preston \& Penner, $1987,1989)$. Although a detailed structural model for the core-oligosaccharide region of the LPS of $P$. baemolytica has not been proposed, it is feasible that it resembles the low-molecular-mass lipo-oligosaccharide structure possessed by mucosal pathogens belonging to the genera Neisseria and Haemopbilus, as is the case with $C$. jejuni (Aspinall et al., 1992). This is supported by the fact that variation in the LPS structure of $P$. baemolytica occurs mainly in the core-oligosaccharide region, as in Neisseria 
and Haemopbilus, and not in the O-antigen region as in members of the Enterobacteriaceae. Rough and smooth LPS types have also been described in the related species Actinobacillus pleuropneumoniae (Byrd \& Kadis, 1989) which, like $P$. baemolytica, is a respiratory tract pathogen. Taken together, these observations suggest that the occurrence of smooth and rough LPS types in different isolates of the same species might be an important feature of the LPS in species belonging to the Pasteurellaceae.

The LPS of $P$. haemolytica exhibited greatest diversity in the core-oligosaccharide region with at least four types being recognized. This diversity may be attributed to variation in sugar composition or partial substitution by phosphate (Lacroix et al., 1993). Conversely, with the exception of serotype A11 isolates, only a single Oantigen type was present. The O-antigen of type 4C LPS, present only in serotype A11 isolates, is clearly different from that in the other serotypes, as was also demonstrated by Lacroix et al. (1993). It should also be noted that serotype A11 isolates were considered a separate biotype by Frederiksen (1973) and recent evidence, based on $16 \mathrm{~S}$ rRNA sequence comparison (Davies et al., 1996), suggests that serotype A11 is phylogenetically distinct from the other serotypes. Of the nine LPS types recognized, types $1 \mathrm{~A}, 1 \mathrm{~B}, 2 \mathrm{~A}, 3 \mathrm{~B}$ and $4 \mathrm{C}$ have been described previously (Ali et al., 1992; Lacroix et al., 1993), whereas types 2B, $3 \mathrm{~A}, 4 \mathrm{~A}$ and $4 \mathrm{~B}$ are described here for the first time. The fact that only a single $\mathrm{O}$-antigen type is present in those isolates possessing smooth-type LPS, i.e. types $1 \mathrm{~A}, 2 \mathrm{~A}$, $3 \mathrm{~A}$ and $4 \mathrm{~A}$, suggests that the genes for this part of the LPS molecule have perhaps been obtained relatively recently by horizontal transfer and have not had time to evolve. Nevertheless, the O-antigen genes have had time to become distributed through at least 7 of the 12 serotypes (Table 1). The absence of the O-antigen from a major group of isolates, i.e. the A2 isolates, is interesting and suggests either that the genes have not been incorporated into this serotype or that they have been incorporated but are not expressed.

The pattern of distribution of the LPS types among the 12 serotypes, and the identification of four groups based on LPS types (Table 1), gave some indication as to the relationships of isolates within the different serotypes to each other. Although some LPS types occurred in more than one group, LPS types $1 \mathrm{~A}, 1 \mathrm{~B}$ and $3 \mathrm{~B}, 4 \mathrm{~A}$ and $4 \mathrm{C}$ were the dominant types in each of the four groups and provided some indication of relatedness. However, it is important to realize that possession of identical LPS types does not necessarily indicate a close genetic relatedness, as has been demonstrated in studies on Escherichia coli (Caugant et al., 1985; Selander et al., 1986; Kapur et al., 1992).

\section{OMP profiles}

The apparent relationships of the individual serotypes to each other based on OMP profiles were very similar to those based on LPS profiles (Tables 1 and 2). However, OMP analysis was able to demonstrate relationships between isolates, both within and between serotypes, that
LPS analysis was unable to do. In addition, OMP analysis clearly demonstrated associations between specific OMP profiles and cattle or sheep specificity. For example, within the A1 group, serotype A1 and A6 isolates could be divided into two distinct sub-groups, OMP types 1.1 and 1.2, which were associated with cattle and sheep, respectively (Table 2). Furthermore, serotype A9, A12, A5 and A8 isolates, which were all of ovine origin, had similar OMP profiles to those of ovine A1 and A6 isolates. The overall similarity of the OMP profiles of the isolates within this group suggested that they are closely related.

As well as being characterized by possession of only rough-type LPS (Table 1), the A2 group also had OMP profiles distinct from those of the A1 group (Table 2), observations suggesting that the $\mathrm{A} 1$ and $\mathrm{A} 2$ groups are fundamentally different. These conclusions supported the findings of $16 \mathrm{~S}$ rRNA sequence comparisons which indicated that the A2 serotype is phylogenetically distinct from all of the other serotypes (Davies et al., 1996). Furthermore, greater variation in the OMP profiles of the $\mathrm{A} 2$ isolates compared to those of the A1 group suggested greater diversity within the A2 serotype. As in the A1 and A6 isolates, OMP analysis was able to clearly differentiate between bovine and ovine A2 isolates. The similarity of the OMP profiles of the serotype A14 and A16 isolates with those of the serotype A2 isolates suggested that these two uncommon serotypes were more closely related to the $\mathrm{A} 2$ isolates than to the $\mathrm{A} 1$ isolates and supported the LPS data.

Serotypes A7, A11 and A13 exhibited greater diversity than both the A1 and A2 groups in terms of their OMP profiles (Table 2). The majority of isolates in this group were characterized by the possession of unique OMP profiles, i.e. OMP types 3.1,3.2 and 3.3, and also possessed LPS having the type 4 core-oligosaccharide (Table 2). These isolates were therefore quite distinct from those of the A1 and A2 groups. However, some A7 isolates possessed OMP and LPS profiles similar to those of serotype A1 or A2 isolates. All of the isolates within this group were of ovine origin and had features of their OMP profiles typical of ovine isolates of the A1 and A2 groups.

\section{Clonal relationships}

The clone concept of bacterial populations is now well established and most, but not all, bacterial species have a clonal population structure (Selander \& Musser, 1990; Maynard-Smith et al., 1993). Although multilocus enzyme electrophoresis (MLEE) is the method of choice to analyse bacterial population structure and identify clonal groups, OMP patterns have been demonstrated to be closely associated with electrophoretic types and clones identified by MLEE (Achtman \& Pluschke, 1986; Kapur et al., 1992). Features of clonal population structure are the repeated recovery of isolates of the same clone over wide geographical areas and long periods of time. Confirmation of the clonal structure of $P$. baemolytica came from the fact that isolates belonging to the A1/A6 clonal group originated from the UK, Germany and the USA. Furthermore, isolates obtained from the NCTC were over 20 
years old and had identical OMP profiles to recent field isolates. In this study, five clonal groups and two groups of sub-clones were identified by their capsule/LPS/OMP combinations and host specificities (Table 3). Although the two A2 and the A7 clones are well-defined, each having unique LPS and OMP combinations, the relationship to each other of the bovine-specific A1/A6 and ovine-specific A6/A9 clones is less clear-cut and requires further investigation. The fact that the A1/A6 clone (52 isolates) and two A2 clones (36 isolates) were recovered more frequently than the others probably indicates a higher degree of virulence than the other clones. These findings are in agreement with observations in other pathogenic bacterial species in which the majority of disease cases are caused by a small proportion of the total number of clones (Selander \& Musser, 1990). Although the majority of isolates in the study were recovered from pneumonic animals, four serotype A7 isolates were obtained from the mammary glands or milk of ewes suffering from mastitis. Of these, $3 / 4$ isolates belonged to the A7 group possessing LPS type 3A (Table 2). LPS type $3 \mathrm{~A}$ was relatively rare within the population (only two other isolates of serotypes A1 and A9 possessed this LPS type) so it was significant that three serotype $A 7$ isolates possessing this LPS type should be associated with mastitis. Analysis of further isolates from cases of mastitis may confirm the existence of a specific clonal group, with characteristic surface properties, associated with this condition. The population structure of $P$. baemolytica is currently being investigated by MLEE.

\section{Host and disease specificity}

One of the most significant findings of the present study was the unambiguous and consistent differentiation of bovine and ovine isolates based on OMP profiles. This was most clearly observed in the bovine and ovine serotype A1, A6 and A2 isolates, but isolates of the other serotypes all possessed features of their OMP profiles characteristic of ovine isolates. At the present time it is not known whether differences in OMP expression are actually responsible for the observed host specificity or whether they are markers of host specificity, having no direct role in specificity. The observations do, however, provide a focus for further work to account for the association of different isolates with cattle and sheep. The role of the different LPS types in virulence and host specificity also needs to be addressed. The association of smooth LPS of type $1 \mathrm{~A}$ with bovine disease and rough LPS of types $1 \mathrm{~B}$ and $3 \mathrm{~B}$ with ovine disease (Table 2) suggested a role for LPS in host specificity. However, when bovine and ovine $\mathrm{A} 1$ and $\mathrm{A} 6$ isolates are examined separately, it is apparent that type 1A LPS is the most common LPS type in ovine, as well as bovine, isolates of each of these serotypes (Table 2). Furthermore, the fact that $\mathrm{A} 9, \mathrm{~A} 12$ and $\mathrm{A} 5$ isolates possessed predominantly smooth LPS of type 1A, and also originated from sheep, suggests that smooth-type LPS may not be the only factor responsible for the observed host specificity. Further evidence is provided by the presence of both smooth and rough LPS types in serotype A7 isolates, which were all derived from sheep (Table 2). Nevertheless, the high frequency of type 1A LPS associated with cattle, and type 1B and 3B LPS associated with sheep, does suggest a possible role of LPS in host specificity and virulence which deserves further investigation. In particular, the role of these different LPS types in adherence to respiratory tract tissue of cattle and sheep needs to be investigated in the light of the finding by Paradis et al. (1994) that the $\mathrm{O}$-antigen of Actinobacillus pleuropneumoniae LPS is involved in adherence to porcine respiratory tract cells. However, the association of specific clonal groups, possessing characteristic capsular polysaccharides, LPS types and OMP profiles, with disease in cattle or sheep (Table 3) suggests that all three cell-surface components may be involved in host specificity and virulence. The variation in host specificity and virulence demonstrated by these clonal groups is analogous to that seen in Bordetella bronchiseptica in which different electrophoretic types are associated primarily with pigs and dogs (Musser et al., 1987).

In summary, comparison of the LPS and OMP profiles of the 12 serotypes of $P$. haemolytica proved extremely useful for assessing diversity within individual serotypes and examining relationships between isolates of different serotypes. In particular, the ability to differentiate between isolates of the same serotypes by a combination of LPS and OMP analysis will be of significant benefit to epidemiological studies of $P$. haemolytica. Based on LPS types and OMP profiles, $P$. baemolytica was shown to consist of four main groups of isolates which may be represented, in terms of their serotypes, as follows: (1) A1, A6, A9, A12, A5 and A8; (2) A2, A14 and A16; (3) A7 and A13; and (4) A11. Significantly, bovine and ovine isolates could be clearly differentiated by their OMP profiles, although capsular polysaccharide types and LPS types also exhibited bovine and ovine specificity.

\section{ACKNOWLEDGEMENTS}

This investigation was supported by a Wellcome Taxonomy Fellowship to R. L. Davies (Ref: 038464/Z/93/Z/REH/MW). The study would not have been possible without the help and co-operation of various individuals at the following Veterinary Investigation Centres: Aberdeen, Auchincruvie, Dumfries, Edinburgh and St Boswells (Scotland); Bristol, Bury St Edmunds, Newcastle, Penrith, Shrewsbury, Sutton Bonington (England); and Aberystwyth and Carmarthen (Wales). We are particularly grateful to Dr David Dyson (Penrith) and Dr Chris Low (Edinburgh) for their interest, advice and help. American and German isolates were kindly provided by Dr G.H. Frank and Professor D. Schimmel, respectively, to whom we are also most grateful. We also thank Norman Tait for the photographic work.

\section{REFERENCES}

Abdullah, K. M., Lo, R. Y. C. \& Mellors, A. (1990). Distribution of glycoprotease activity and the glycoprotease gene among serotypes of Pasteurella baemolytica. Biochem Soc Trans 18, 901-903.

Achtman, M. \& Plushke, G. (1986). Clonal analysis of descent and virulence among selected Escherichia coli. Annu Rev Microbiol 40, 185-210. 
Adlam, C. (1989). The structure, function and properties of cellular and extracellular components of Pasteurella baemolytica. In Pasteurella and Pasteurellosis, pp. 75-92. Edited by C. F. Adlam \& J. M. Rutter. London: Academic Press.

Ali, Q., Davies, R. L., Parton, R., Coote, J. G. \& Gibbs, H. A. (1992). Lipopolysaccharide heterogeneity in Pasteurella baemolytica isolates from cattle and sheep. J Gen Microbiol 138, 2185-2195.

Aspinall, G. O., McDonald, A. G., Raju, T. S., Pang, H., Mills, S. D., Kurjanczyk, L. A. \& Penner, J. L. (1992). Serological diversity and chemical structures of Campylobacter jejuni low-molecular-weight lipopolysaccharides. J Bacteriol 174, 1324-1332.

Byrd, W. \& Kadis, S. (1989). Structures and sugar compositions of lipopolysaccharides isolated from seven Actinobacillus pleuropneumoniae serotypes. Infect Immun 57, 3901-3906.

Caugant, D. A., Levin, B. R., Orskov, I., Orskov, F., Svanborg Eden, C. \& Selander, R. K. (1985). Genetic diversity in relation to serotype in Escherichia coli. Infect Immun 49, 407-413.

Davies, R. L. \& Quirie, M. (1996). Intra-specific diversity of Pasteurella trebalosi based on variation of capsular polysaccharide, lipopolysaccharide and outer-membrane proteins. Microbiology 142, $551-560$.

Davies, R. L., Ali, Q., Parton, R., Coote, J. G., Gibbs, H. A. \& Freer, J. H. (1991). Optimal conditions for the analysis of Pasteurella baemolytica lipopolysaccharide by sodium dodecyl sulphatepolyacrylamide gel electrophoresis. FEMS Microbiol Lett 90, 23-28.

Davies, R. L., Parton, R., Coote, J. G., Gibbs, H. A. \& Freer, J. H. (1992). Outer membrane protein and lipopolysaccharide variation in Pasteurella baemolytica A1 under different growth conditions. $J$ Gen Microbiol 138, 909-922.

Davies, R. L., Parton, R., Coote, J. G., Gibbs, H. A. \& Freer, J. H. (1994). Evaluation of different methods for the detection of outer membrane proteins and lipopolysaccharides of Pasteurella baemolytica by immunoblotting. J Immunol Metbods 167, 35-45.

Davies, R. L., Paster, B. \& Dewhirst, F. (1996). Phylogenetic relationships and diversity within the Pasteurella haemolytica complex based on 16S rRNA sequence comparison and outer membrane protein and lipopolysaccharide analysis. Int J Syst Bacteriol 46, (in press).

Filip, C., Fletcher, G., Wulff, J. L. \& Earhart, C. F. (1973). Solubilization of the cytoplasmic membrane of Eschericbia coli by the ionic detergent sodium-lauryl sarcosinate. J Bacteriol 115, 717-722.

Frank, G. H. (1989). Pasteurellosis of cattle. In Pasteurella and Pasteurellosis, pp. 197-222. Edited by C. F. Adlam \& J. M. Rutter. London: Academic Press.

Fraser, J. \& Donachie, W. (1983). Rapid indirect haemagglutination test for serotyping Pasteurella baemolytica. J Clin Microbiol 18, 206-207.

Fraser, J., Laird, S. \& Gilmour, N. J. L. (1982). A new serotype (biotype T) of Pasteurella baemolytica. Res Vet Sci 32, 127-128.

Frederiksen, W. (1973). Pasteurella taxonomy and nomenclature. Contrib Microbiol Immunol 2, 170-176.

Gentry, M. J., Confer, A. W. \& Holland, S. G. (1988). Comparison of the toxic and antigenic properties of single bovine isolates of Pasteurella baemolytica representing five serotypes and an untypable strain. Vet Microbiol 16, 351-367.

Gerbig, D. G., Cameron, M. R., Struck, D. K. \& Moore, R. N. (1992). Characterization of a neutralizing monoclonal antibody to Pasteurella baemolytica leukotoxin. Infect Immun 60, 1734-1739.

Gilmour, N. J. L. \& Gilmour, J. S. (1989). Pasteurellosis of sheep. In Pasteurella and Pasteurellosis, pp. 223-261. Edited by C. F. Adlam \& J. M. Rutter. London: Academic Press.
Gilmour, J. S., Jones, G. E., Rae, A. G. \& Quirie, M. (1986). Comparisons of single strains of four serotypes of Pasteurella baemolytica biotype A in experimental pneumonia of sheep. Res $V e t$ Sci 40, 136-137.

Hitchcock, P. J. \& Brown, T. M. (1983). Morphological heterogeneity among Salmonella lipopolysaccharide chemotypes in silverstained polyacrylamide gels. J Bacteriol 154, 269-277.

Kapur, V., White, D. G., Wilson, R. A. \& Whittam, T. S. (1992). Outer membrane protein patterns mark clones of Escherichia coli $\mathrm{O} 2$ and O78 strains that cause avian septicaemia. Infect Immun 60, 1687-1691.

Lacroix, R. P., Duncan, J. R., Jenkins, R. P., Leitch, R. A., Perry, J. A. \& Richards, J. C. (1993). Structural and serological specificities of Pasteurella baemolytica lipopolysaccharides. Infect Im mun 61, 170-181. Laemmli, U. K. (1970). Cleavage of structural proteins during the assembly of the head of bacteriophage T4. Nature 227, 680-685.

McCluskey, J., Gibbs, H. A. \& Davies, R. L. (1994). Variation in outer-membrane protein and lipopolysaccharide profiles of Pasteurella baemolytica isolates of serotypes A1 and A2 obtained from pneumonic and healthy cattle. Microbiology 140, 807-814.

Markwell, M. A. K., Haas, S. M., Bieber, L. L. \& Tolbert, N. E. (1978). A modification of the Lowry procedure to simplify protein determination in membrane and lipoprotein samples. Anal Biochem 87, 206-210.

Maynard Smith, J., Smith, N. H., O'Rourke, M. \& Spratt, B. G. (1993). How clonal are bacteria? Proc Natl Acad Sci USA 90, 4384-4388.

Murphy, G. L., Robinson, L. C. \& Burrows, G. E. (1993). Restriction endonuclease analysis and ribotyping differentiate Pasteurella baemolytica serotype A1 isolates from cattle within a feedlot. $\mathrm{J}$ Clin Microbiol 31, 2303-2308.

Musser, J. M., Bemis, D. A., Ishikawa, H. \& Selander, R. K. (1987). Clonal diversity and host distribution in Bordetella bronchiseptica. $J$ Bacteriol 169, 2793-2803.

Mutters, R., Bisgaard, M. \& Pohl, S. (1986). Taxonomic relationship of selected biogroups of Pasteurella baemolytica as revealed by DNA : DNA hybridizations. Acta Path Microbiol Immunol Scand B94, 195-202.

Mutters, R., Mannheim, W. \& Bisgaard, M. (1989). Taxonomy of the group. In Pasteurella and Pasteurellosis, pp. 3-34. Edited by C. F. Adlam \& J. M. Rutter. London: Academic Press.

Paradis, S. E., Dubreuil, D., Rioux, S., Gottschalk, M. \& Jacques, M. (1994). High-molecular-mass lipopolysaccharides are involved in Actinobacillus pleuropneumoniae adherence to porcine respiratory tract cells. Infect Immun 62, 3311-3319.

Preston, M. A. \& Penner, J. L. (1987). Structural and antigenic properties of lipopolysaccharides from serotype reference strains of Campylobacter jejuni. Infect Immun 55, 1806-1812.

Preston, M. A. \& Penner, J. L. (1989). Characterization of cross reacting serotypes of Campylobacter jejuni. Can J Microbiol 35, 265-273.

Quirie, M., Donachie, W. \& Gilmour, N. J. L. (1986). Serotypes of Pasteurella baemolytica from cattle. Vet $\operatorname{Rec} 119,93-94$.

Selander, R. K. \& Musser, J. M. (1990). Population genetics of bacterial pathogenesis. In The Bacteria, pp. 11-36. Edited by B. $\mathrm{H}$. Iglewski \& V. L. Clark. London: Academic Press.

Selander, R. K., Korhonen, T. K., Vaisanen-Rhen, V., Williams, P. H., Pattison, P. \& Caugant, D. A. (1986). Genetic relationships and clonal structure of strains of Escherichia coli causing neonatal septicaemia and meningitis. Infect Immun 52, 213-222.

Sneath, P. H. A. \& Stevens, M. (1990). Actinobacillus rossii sp. nov., 
Actinobacillus seminis sp. nov., nom. rev., Pasteurella bettii sp. nov., Pasteurella lymphangitidis sp. nov., Pasteurella mairi sp. nov., and Pasteurella trebalosi sp. nov. Int J Syst Bacteriol 40, 148-153.

Tsai, C. M. \& Frasch, C. E. (1982). A sensitive silver stain for detecting lipopolysaccharide in polyacrylamide gels. Anal Biochem 119, 115-119.
Younan, M. \& Fodor, I. (1995). Characterisation of a new Pasteurella baemolytica serotype (A17). Res Vet Sci 58, 98.

Received 29 December 1995; revised 28 February 1996; accepted 5 March 1996. 